\title{
Muraqabah intensification therapy (MIT): an alternative Islamic therapy for social media addiction
}

\author{
Winda Sri Harianti, Rafifah Huwaida, Nindya Sekar Adriwiguna, Hazhira Qudsyi \\ Department of Psychology, Faculty of Psychology and Socio-cultural Sciences, Universitas Islam Indonesia, Yogyakarta, Indonesia
}

\begin{abstract}
Article Info
Article history:

Received Jul 12, 2021

Revised Oct 28, 2021

Accepted Nov 9, 2021

Keywords:

Behavioral addiction

Islamic psychology

Muraqabah

Social media

Spiritual intervention

ABSTRACT

This era has been witnessing an increasing sophistication in the technological development, which had an impact on people's quality of life. For instance, many kinds of currently evolving social media ease mutual communication and interaction among individuals. Nevertheless, there has been an increasing concern over the usage of social media given its excessive use and its adverse impacts. Some evidences of excessive social media usage share some similar indicators categorized into behavioral addiction. This phenomenon is increasingly alarming because technological development is inseparable from human life. Nowadays, there have been many methods offered to overcome social media addiction. Accordingly, the purpose of this study was to examine muraqabah (Islamic mindfulness or self-monitoring) concept as a spiritual intervention based on Islamic tenet to overcome addictive behavior using an integrative literature review from previous empirical studies that have been conducted in Indonesian and English both in qualitative and quantitative methods. The result from previous study has been proven that daily practical of muraqabah can manage the primary psychological aspects of humans and increase human's self-actualization. Therefore, this therapy model can be an effective and alternative way to cope with social media addiction and prevent a possibility of relapse behavior.
\end{abstract}

This is an open access article under the CC BY-SA license.

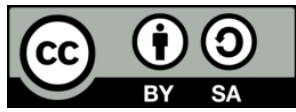

\section{Corresponding Author:}

Winda Sri Harianti

Department of Psychology, Faculty of Psychology and Socio-cultural Sciences, Universitas Islam Indonesia

Kaliurang Km 14,5 Street, Ngemplak, Sleman, 55584, Special Region of Yogyakarta, Indonesia

Email: windasri17@gmail.com

\section{INTRODUCTION}

The discussion regarding internet and technological development is inseparable from the use of social media as an influential element that raises many debates due to the emergence of public concern. This debate arises due to the excessive or maladaptive use of social media [1]-[4]. Previous study also stated that social media can contribute to negative consequences, such as disorder and diseases if used improperly [5]. At present time, there has been an alarming concern on the risk of technological development on its users, especially in several cases, such as lack of consideration, uncontrolled use of the technology, and uncontrollably excessive usage of technology. Based on this, the use of technology has an indirect impact or consequence on its users [6].

Addiction is a complex disorder, as an indicated by some diagnostics on the inclination in using a particular substance repeatedly and compulsivity or indulging in a particular behavior in spite of negative consequence [2]. Addiction is closely related with a brain disease, as depicted by person's incapability to stop nonadaptive or dysfunctional behavior because of drugs or other activities that we did repeatedly in spite of 
prejudicial consequences. The disease of addiction interferes the brain's functions and activities as in the cognitive function and causes some impacts, such as inhibiting the acquisition of adaptive behavior [7]. Addiction is not only about drug-consumed behaviors, but also about the part of biopsychosocial process [1]. Addiction for the most part are chronic, progressive, and greatly destructive [2]. It is generally agreed that types of addiction are classified into psychological or behavioral addiction. Behavioral addiction occurs when someone becomes addicted to activities, such as gambling or shopping. A behavioral or psychological addiction is also known as a process of addiction. However, some prefer to call it behaviors of impulsive control disorders or obsessive-compulsive disorders, which have led to their popular identification as addictions. At the beginning, this type of addiction provides some kinds of pleasure, gratification, and excitement [2]. This fact is evident in some recent social phenomenon, which revealed the social media use as a bustle among adolescent that cannot be avoided any more [8]. Using social media applications, in fact, can cause addiction and entice the user's feeling on it [5].

Social media addiction can be shown through several indicators, such as being engrossed in social media, using social media with the intention to reduce negative feelings, using social media gradually, increasing the attempt to get pleasure from it, experiencing stress if prohibited from using social media, sacrificing the need of others and disturbing the lives of others, and losing control when using it [9]. Some symptoms of social media addiction are apparent from person's behavior, such as hoping that the object or behavior can bring excitement, feeling grumpy and uneasy when prevented from the substance or behavior, spending time for the substantial use or activity, disregarding main responsibility at school, home, or work, feeling obsessively about the activity, refuting that there is a problem of it from oneself and others even though it evinces negative effects [2].

It is revealed that there has been an increasing cases of social media addiction and that it has a great impact on people's quality of life [5]. In fact, the current phenomenon shows that social media use has now become such a pervasive and obtrusive force in university students' lives and that interactions with others on social media may give a new or different definition, and engagement in particular activities, including addictive behaviors [10]. Social media addiction is a phenomenon that needs our concern because addictive behavior is unlike excessive use behavior [11]. Addictive behavior can bring up symptoms of psychopathological problems, such as relapse, mood modification, salience, and conflict. These symptoms are caused by compulsive usage of social media [1].

The global data as shown in Figure 1 sosial media user in (a) Indonesia and (b) World indicates that the total population is greater than the total number of mobile phone users and that the total internet users are greater than the total active social media users. In Indonesia, the total number of mobile phone users is greater than the total population. Data show that active social media user reaches $59 \%$ of the total population. From this, we can conclude that our life cannot be separated from the current technological advancement. However, the increasing active social media users raise concerns due to negative consequences for users, such as social media addiction. This fact is in accordance with a recent study portraying that the uncontrolled intensity in using social media can lead to social media addiction [12].

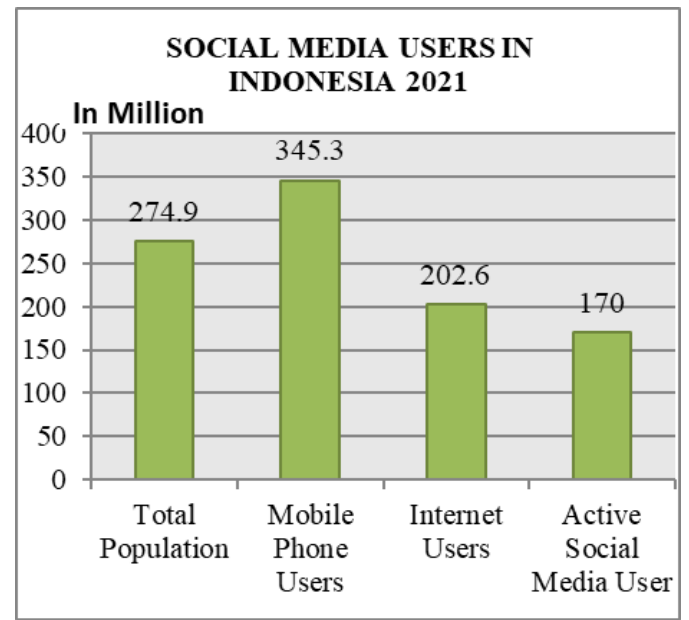

(a)

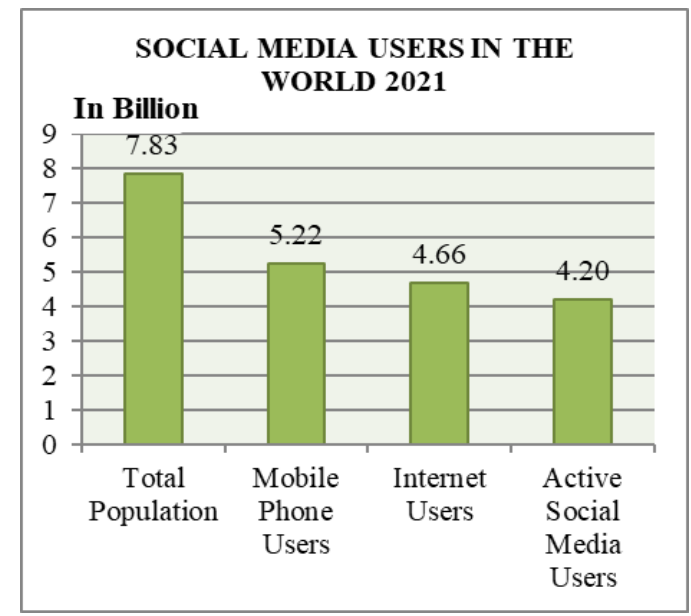

(b)

Figure 1. Social media users in: (a) Indonesia and (b) Worldwide (source: https://wearesocial.com/digital2021) 
This case is evident because addiction is observable from some aspects as a set of behavior that violates the religious, moral, or legal codes of conduct [13]. The previous study showed that people with social media intrusion have a low level of spiritual well-being [14]. Another study revealed that spirituality serves as one of applicable essential aspects on dealing with drugs problem [15]. This study used an Islamic approach due to the total population of Muslims that reached 1.8 billion in the world [16] and the fact that Asia has the largest number of Muslim population as compared to other continents. However, there are minorities of Muslim population in almost every region [15]. In Asia, Indonesia is the country that has the largest number of Muslim populations, which constituted $87 \%$ of the total Muslim population worldwide [17]. Therefore, the method of this study is inseparable from the religious values of Muslim population [18].

On this basis, spiritual intervention is a necessary therapy to overcome social media addiction because behavior addiction seen as immoral behavior [13]. Previous study found that the practice of muraqabah (Islamic mindfulness or self-monitoring) was proven to be able to maintain individual obedience to not do bad deeds. The study also found that muraqabah is effective for maintaining individual attitudes and behavior related to spirituality and morality [19]. Not only that, muraqabah has been proven to be able to control psychological aspects and disorder, such as severe depression, personality disorder, bipolar, and attention-deficit disorder [20], stress [21], depression [22], [23], and anxiety [20], [22]. Thus, this study proposes muraqabah as an alternative approach to overcome psychological disorder based on Islamic tenet, which not only focus on how to overcome behavior problems, but also intend to maintain positive behavior and psychological conditions that have been developed by this therapy. This has been proven by great positive impacts from Islamic contemplation practices through a meta-study [24]. Another finding also shown that Islamic mindfulness has great contribution to higher mental health [25]. Last, preventing relapse is a crucial issue in dealing with addiction and becomes the fundamental key of successful interventions on behavioral addiction [26]. This approach involves the relation between people and their God throughout human's life and it can be applied to prevent the increasing possibility of repeatable symptoms and behavior of behavioral addiction.

\section{RESEARCH METHOD}

\subsection{Data source}

This study examined muraqabah concept based on Islamic tenet and proposed a therapy model based on muraqabah concept as an alternative solution to overcome behavioral addiction, especially social media addiction. This study was using a literature review method, particularly integrative review. The purposes of this study is in accordance with integrative review method, which aims to overview and examine the knowledge base, even to reconceptualize and to expand the conceptual foundation for a particular topic [27]. The data used in this study were collected from previous empirical studies on related topic. There are several criteria for articles to be included in this study, such as articles that conducted in two different languages: English and Bahasa (the two languages professed by the researchers), and articles that examine the concept of muraqabah, or Islamic self-monitoring, or Islamic mindfulness concept/therapy both in quantitative or qualitative methods. There is no time limit on the year of the article were published. This consideration is based on the topics studied are clearly specified and the existing research reference are quite limited. However, researchers still prioritize the latest relevant research to involve in this study. The articles that do not meet these criteria are not included in this study.

\subsection{Research procedure}

In general, there are four phases carried out in the literature review process: i) designing, ii) conducting, iii) analysis, and then iv) structuring and writing the review [27]. Designing the review is the first phase, which aimed to formulate and clearly specify the purpose and scope of the research question. The second phase is conducting or the stage that is related to the search process and strategy as well as the study selection process. The study selection process is a very crucial stage because of the data, which obtained will be the main reference in writing research results and building a conceptual framework that is in accordance with the research objectives. The next process is analysis the selection studies and the final stage is writing the review. However, this research does not focus on the process of presenting the results of the review, but uses the results of the review as a theoretical framework to develop the new conceptual or theoretical framework for designing a therapy model. It based on integrative review model that focus to generate an advancement knowledge, a new theoretical or conceptual framework, rather than a simply overview or a descriptive study [27]. 


\subsection{Data analysist}

This stage will focus on the process of abstracting and extracting information from selected articles that will be used in reviewing and answering the research questions. The form of extracting the information can be a description or a conceptualization particular ideas or can be vary in accordance with the purpose of study or research question [27]. In the final result, this study portrays the concept of muraqabah as a spiritual intervention, which can control behavior, feeling, and cognitive aspects and depicts the main stages and the implementation strategy model of muraqabah therapy to overcome social media addiction based on the empirical supporting data. This study results a new conceptual model of a therapy design. According to a literature review study design, its is suitable for a study to use an integrative review process ir the purposes of the research was to develop a theoretical model or framework [27].

\section{RESULTS AND DISCUSSION}

\subsection{Muraqabah based on Islamic tenet}

The contemporary society has been witnessing how addictive behaviors including drug use and internet use can affect anyone. These types of addiction may lead to massive impact, not only on the individual users, but also on their relatives, communities, and the entire society and their economy at large [15]. We used Islamic intervention, muraqabah, as a way to overcome social media addiction because spirituality and religiosity are two essential aspects in human life, especially since they also incur a considerable impact on behavior addiction. In addition, people used these substances to fill their spiritual emptiness and meaninglessness based on spiritual model [13]. Spiritual mentality is very significant for human life since without a strong base in high religious value, this mental spiritual will fade away and it will have a lot of influence on behavior and mental attitude [19].

In Islamic intervention, muraqabah is an extremely important thing for someone to oversee all of their deeds according to God's provisions [19]. Muraqabah is a state of affairs when an individual constantly understands and believes in God's surveillance. In addition, muraqabah is a state when we are convinced that God always observes and sees our behaviors, and also hears everything that we say [28]. Muraqabah in Islamic perspective is a condition of awareness in someone that God is constantly watching and monitoring him or her. Hence, this fact significantly serves as the most important mechanism in changing person's thought or behavior [15]. From the previous studies, some defined muraqabah as Islamic self-monitoring [29] and Islamic mindfulness concept [20], [30]. However, there is no difference in essence that is explained regarding the concept of muraqabah. When muraqabah is applied in people's life, they might maintain their positive behavior and become more thoughtful in behaving. This matter will prevent someone from useless deeds, which are deemed inappropriate in God's provision. With muraqabah, we constantly keep an eye on ourselves in order to prevent us from undesirable behavior and to maintain us from behavioral changes [15].

As a Muslim, we need to know that Allah SWT has granted us with logic and intelligence to differentiate the good thing from the bad thing. However, we also need to control our desire since our ignorance on controlling the desire will lead to a bad impact. The desire is not standing alone, but it is standing with foolishness. In other words, when an individual knows of something dangerous, he/she individual will have an attempt to avoid that. One of the reasons why negative behaviors may lead to foolishness is the fact that an individual of limited knowledge will consider their deed as beneficial [31]. The Quran has a saying which perfectly portrays this condition as mentioned in the following verse:

"... and do not obey one whose heart we have made heedless of our remembrance and who follows his desire and whose affair is ever (in) neglect." (Qur'an 18:28)

This explanation indicates how muraqabah can control human behavior, particularly in preventing someone from having a despicable behavior and possibly of repeatable behavior. This study used a horizontal and vertical therapeutic practice model. Horizontal model is intended for the relationship between human and himself by maximizing the power that exists in human and those around him. Meanwhile, the vertical relationship is a human relationship with God by seeking strength from God for the problems faced and returning all problems and asking for God's guidance. Realizing and being convinced that Allah always observes our deeds can bring out the feeling of human's regret and repentance (tawba) in ourselves. In Islam, Allah has commanded Muslims to immediately realize and repent (tawba) when making a mistake. Furthermore, repentance (tawba) is the first step to improve behavior and muraqabah is included in the process of repentance (tawba) [19].

A recent research proves how muraqabah is capable of maintaining adab (behavior), which is norms or rules regarding manners based on religious rules, especially applied for Muslims who served as $70 \%$ of the research participants [19]. Another research revealed that muraqabah is able to prevent someone from dishonest behavior and integrity violation on college students [29] and also become an effective therapy 
for psychological disorders, such as depression, bipolar, stress, anxiety, personality disorder, and attentiondeficit disorder [20]-[23], [32]. When someone has habituated muraqabah in himself, he will be capable of restraining his inner lust and behavior to avoid negative impact on himself [28] because muraqabah serves as a deterrence system in human from all bad intentions and behavior [33].

\subsection{Muraqabah intensification therapy (MIT) model to overcome social media addiction}

In essence, there have been many methods and interventions done to overcome behavioral addiction, especially for social media addiction. Nevertheless, there is no single treatment, which is proven to be appropriately applicable to everyone. In fact, the success of therapy highly depends on subject's condition and needs since there are many aspects that can affect the various strategies of intervention [15]. A spiritual intervention is one of such method. It has been widely used to overcome some types of addiction, such as transcendental meditation based on Eastern Spiritual Practice [34], Native American Spirituality [13], and Islamic approach [15].

Spiritual intervention can become one of comprehensive approaches which can be used for overcoming behavioral addiction. It is in line with previous study, which found that bio-psycho-social and spiritual intervention can serve an intervention to overcome behavioral addiction (drugs user and gambling) [15]. However, the essence of recovery in that problem is spiritual guidance and spiritual intervention [15]. Moreover, behavioral addiction is seen as an immoral behavior and is related with the sinful behavior according to the moral perspective [13]. In addition, spiritual approach is proven to improve individual's mental health [15], [35]-[37], and physical health [35], and overcome the clinical obstacle in counseling and therapeutic process [38], self-actualization [19], treatment on drugs, alcohol and gambling problems [15], treatment for substance-related disorder [39], treatment for psychopathology due to social media addiction [40], and drug rehabilitation [41].

"Spiritual models all share a recognition of the limitations of the self and a desire to achieve health through a connection with that which transcends the individual." (Substance Abuse and Mental Health Service Administration, 2012)

Other than that, there is a phase of "cured and relapsed" in overcoming the problem of addiction, which makes the treatment a long-term process [15]. However, for Muslims, the phase of long-term recurrence of resistance can be achieved by conducting intensive spiritual interventions. In Islam, spiritual intervention is done by drawing ourselves closer to Allah, by doing daily spiritual worship, such as prayer, salaat, dhikr, fasting, reading Holy Qur'an, and other various positive behaviors. When all these activities are done constantly, they can help individuals to develop the good character in themselves [15], [42]. On this account, it is true that adhering to the principles and practices of Islamic religion is proven to cause psychological adjustment, better mental health [15], [43], and also has been recommended for improving clinical practice [44], [45], psychotherapy [46], [47] and psychological intervention [48].

\subsection{Muraqabah intensification therapy (MIT) model}

This therapy is an individual model consisting of several series of sessions. However, it can be the form of group sessions. The therapy uses series of methods to maximize the goals of each session. The purpose of this therapy is to instill and strengthen attitudes and principles in muraqabah, the attitude of the belief that God supervises all human actions and improves the spiritual quality of the individual by strengthening daily spiritual activities and combining several concepts in Islam to maximize the purpose of the therapy. Aside from aiming to help individuals overcome addictive behavior, this therapy also aims to help individuals live their lives better and be beneficial to themselves and those around them in the future. Thus, we formulated the therapy into three main stages: awakening, habituating and reinforcing, and strengthening (Figure 2). This formulation is compiled based on an Islamic counseling stages to overcome addictive behavior [15]. The figure explains the stages of this therapy.

\subsubsection{Awakening stage}

At this stage (Figure 2), individuals have come to realize how their behavior has led to adverse impacts on them and thus, they start to feel the urge to change it. Then, the individuals are directed to admit all their mistakes and build confidence to avoid repeating the bad behavior. This stage primarily aims to make the individuals realize their bad behavior, build and strengthen their intention to change and stay away from the behavior. This goal will be achieved through a combination of activities, such as understanding and deepening self-awareness, building inner intention (niyyah), deepening the tafakkur (contemplation) process, repentance (tawba), and conducting salaat al-tawba (repentance prayer). 


\subsubsection{Habituating and reinforcing stage}

This stage aims to familiarize, improve and strengthen individuals with daily worship, such as salaat (prayers), praying, dhikr, and reciting the Qur'an as well as other forms of worship in a constant manner. These worship services are proven to be able to change a person's heart, keep people away from lamentable behavior, increase individuals' self-actualization and bring them closer to God. The daily worship is habituated since the beginning of therapy, and it is constantly performed every day during the therapy session until the end of the session and shall continue in the individuals' daily life even after completing the therapy session. This therapy is directed to help individuals draw their hearts, minds, and behavior closer to God so as to instill a belief in individuals that God is always watching every human behavior. This stage is achieved through habituation and reinforcement of the daily religious activities of Muslims (Figure 2).

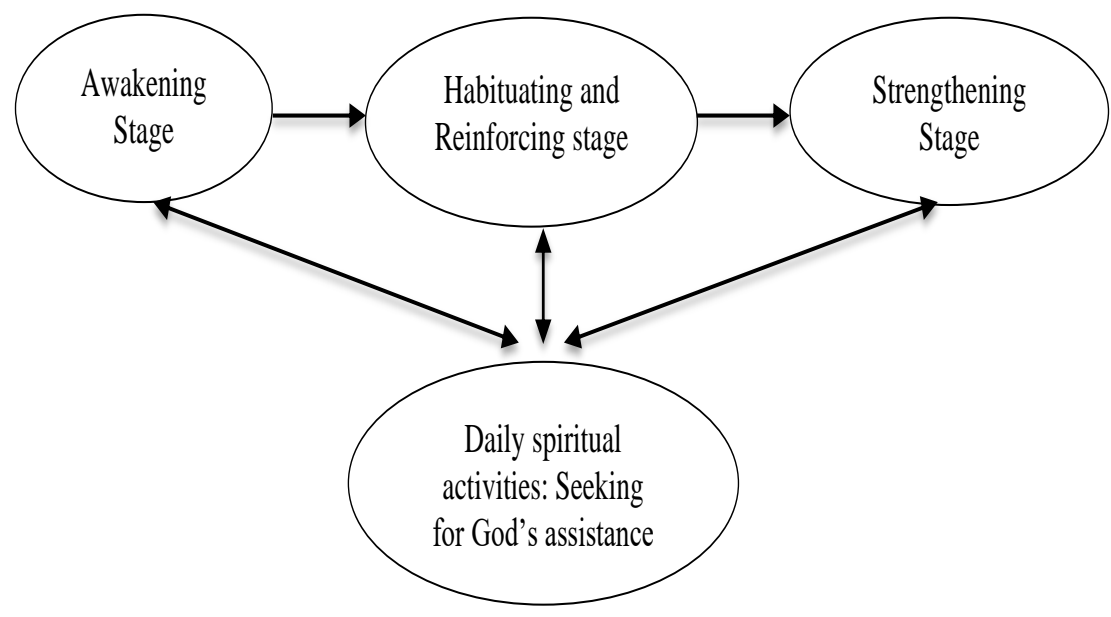

Figure 2. The main stage of muraqabah intensification therapy (MIT) to overcome social media addiction

\subsubsection{Strengthening stage}

This stage is emphasized on the attempt to strengthen the results of the habituating and reinforcing stages through several additional activities (Figure 2). The primary challenge in overcoming addictive behavior is the relapse phase that normally occurs in individuals even after receiving therapy or medication. Hence, this stage serves as an effort to prevent the relapse phase of addictive behavior. Additional activities include understanding and deepening the concept of human creation and the primary purpose of human life in the world based on human nature, understanding and cultivating a patient attitude ( $s a b r$ ), gratitude, obeying religious rules (taqwa), and habituating to carry out self-evaluations or muhasabah. Each of these activities is mainly aimed at strengthening thoughts and feelings that will direct individual behavior in accordance with the intended purpose, namely a change for the better. This stage will strengthen one's belief that Allah is always watching and seeing what every human being is doing and each individual will get a reward for his behavior. In fact, this session will help individuals who have changed from addictive behavior to live a future better life and focus on things that are beneficial to themselves and those around them.

This study proposes a new alternative therapy model to overcome psychological disorder, particularly on behavioral problems such as social media addiction. In addition, this therapy model is highly applicable for any psychological disorders to control human emotional, cognitive, and behavior disorders. This therapy was designing as a new alternative solution from Islamic perspective to complement the existing psychotherapy or counseling for behavioral addiction, which is still endeavoring to overcome the relapse phase that often occurs after giving the intervention. It is an accordance with a previous critical review which found that the necessity to refine the strategies for maintaining the effect of therapy is precarious, such as by developing behavioral and pharmacological therapy [26]. Muraqabah intensification therapy (MIT) is designed to prevent the possibility of relapse phase after giving the treatment by adapting the habits and practices of worship in Islam, which have been proven to be able to influence the psychological aspects of individuals. It is in line with the goal of treatment that should help individuals for developing the recognizing skill of early warning signs of relapse phase and developing a coping strategy to prevent the relapse phase of addiction problems [49]. This therapy is also designed as a solution to psychological problems that are urgently needed by considering spiritual and religious factors, especially in overcoming psychological problems in Muslim clients. This will be very helpful for helping professions who tend to meet Muslim 
clients in practice, teaching, and research [50], because even just an understanding of the models and the concepts in the context of Islam is likely to have a big positive impacts on Muslim clients [18]. Most importantly, Islam is a divine religion with universal standart - not for particular ras, class, or family - its goes beyond all times and places [51].

\section{CONCLUSION}

Previous studies have proven that spiritual interventions not only overcome social media addiction, but also improve one's spirituality and can have an impact on one's self-actualization process, as done in the interventions applying an Islamic approach. Muraqabah intensification therapy (MIT), which proposed by this study can be used to overcome social media addiction that consists of three stages, namely awakening, habituating and reinforcing, and strengthening. These stages serve as a method to help a person realize and admit their mistakes, strengthen a person to make some changes in himself, especially in overcoming the addictive behaviors they suffer from, and reinforce the therapy impact and its positive effects on their feelings, thoughts, behavior to constantly stay away from bad behavior as a way to live a better life in the future. This therapy applies to subjects who are aware of their condition and have the urge to change their addictive behavior. Meanwhile, subjects who are yet to aware of their addictive behavior need to conduct a certain stage before entering this stage of therapy. The success of this therapy is determined by the level of one's faith in God. However, this therapy model is still at the conception stage. In addition, researchers suggest the need to have a further test on the design of this therapy model to see its effect and effectiveness on human behavior problems, particularly on addictive behavior.

\section{ACKNOWLEDGEMENTS}

Authors thank to Universitas Islam Indonesia for the financial support to publish this research on international journal. Authors also thank to Department of Psychology, Universitas Islam Indonesia and family for their special support for authors to accomplish this research.

\section{REFERENCES}

[1] M. Griffiths, “A 'components' model of addiction within a biopsychosocial framework," J. Subst. Use, vol. 10, no. 4, pp. 191197, 2005, doi: 10.1080/14659890500114359.

[2] K. H. Hollen, Encyclopedia of Addictions. London: Greenwood Publisher, 2009. https://id1lib.org/book/610086/727708 (accessed August 8, 2020).

[3] L. Leung, "Predicting Internet risks: a longitudinal panel study of gratifications-sought, Internet addiction symptoms, and social media use among children and adolescents," Heal. Psychol. Behav. Med., vol. 2, no. 1, pp. 424-439, 2014, doi: $10.1080 / 21642850.2014 .902316$

[4] F. A. Mahamid and D. Z. Berte, "Social media addiction in geopolitically at-risk youth," Int. J. Ment. Health Addict., vol. 17, no. 1, pp. 102-111, Feb. 2019, doi: 10.1007/s11469-017-9870-8.

[5] M. Altın and A. O. Kıvrak, "The Social media addiction among Turkish University students," J. Educ. Train. Stud., vol. 6, no. 12, p. 13, 2018, doi: 10.11114/jets.v6i12.3452.

[6] T. Akter, "Social media addiction, resistance, and influence of awareness: Measurement of psychology students' resistance to Facebook addiction," Mediterr. J. Soc. Sci., vol. 5, no. 8, pp. 456-464, 2014, doi: 10.5901/mjss.2014.v5n8p456.

[7] T. J. Gould, "Addiction and cognition," Addict. Sci. Clin. Pract., vol. 5, no. 2, pp. 4-14, 2010.

[8] P. Q. Ayun, "The phenomenon of peens using social media in forming identity (In Indonesia: Fenomena remaja menggunakan media sosial dalam membentuk identitas)," Channel J. Komun., vol. 3, no. 2, pp. 1-15, 2015, doi: 10.12928/channel.v3i2.3270

[9] C. S. Andreassen, S. Pallesen, and M. D. Griffiths, "The relationship between addictive use of social media, narcissism, and selfesteem: Findings from a large national survey," Addict. Behav., vol. 64, pp. 287-293, 2017, doi: 10.1016/j.addbeh.2016.03.006.

[10] M. L. N. Steers, M. A. Moreno, and C. Neighbors, "The influence of social media on addictive behaviors in college students," Curr. Addict. Reports, vol. 3, no. 4, pp. 343-348, 2016, doi: 10.1007/s40429-016-0123-x.

[11] O. Turel and A. Serenko, "The benefits and dangers of enjoyment with social networking websites," Eur. J. Inf. Syst., vol. 21, no. 5, pp. 512-528, 2012, doi: 10.1057/ejis.2012.1.

[12] B. G. A. Arimbawa, M. Arifin, and S. Napisah, "Analysis of social addiction media in the student counseling program at Pgri Banyuwangi University (In Indonesia: Analisa kecanduan media sosial pada mahasiswa program studi bimbingan konseling universitas pgri banyuwangi)," J. Bina Ilmu Cendekia, vol. 2, no. 1, pp. 109-126, 2020.

[13] Substance Abuse and Mental Health Services Administration, Enhancing Motivation For Change in Substance Abuse Treatment. Rockville: Substance Abuse and Mental Health Services Administration, 2012.

[14] M. Wood, H. Center, and S. C. Parenteau, "Social media addiction and psychological adjustment: religiosity and spirituality in the age of social media," Ment. Health. Relig. Cult., vol. 19, no. 9, pp. 972-983, Oct. 2016, doi: 10.1080/13674676.2017.1300791.

[15] H. G. Rassool, Islamic counsellling: An introduction to theory and practice. New York: Routledge, 2016.

[16] Pew Reseacrh Center, "The countries with the 10 largest Christian populations and the 10 largest Muslim populations," Pew Reseacrh Center, 2019. https://www.pewresearch.org/fact-tank/2019/04/01/the-countries-with-the-10-largest-christianpopulations-and-the-10-largest-muslim-populations/\#: :text=Overall\%2C there are about 2.3,world and 1.8 billion Muslims (accessed May 8, 2020).

[17] U.S. Comission on International Religious Freedom, "2017 Annual Report," 2017. https://www.uscirf.gov/sites/default/files/Indonesia.chapter.Bahasa Indonesia.translation.pdf (accessed December 22, 2020). 
[18] H. Keshavarzi and A. Haque, "Outlining a psychotherapy model for enhancing muslim mental health within an Islamic context," Int. J. Psychol. Relig., vol. 23, no. 3, pp. 230-249, 2013, doi: 10.1080/10508619.2012.712000.

[19] H. K. Ummah, "The effectiveness of muraqabah for self-actualization of students (In Indonesia: Efektivitas muraqabah bagi aktualisasi diri santri)," Syifa Al-Qulub, vol. 3, no. 2, pp. 41-52, 2018.

[20] N. Isgandarova, "Muraqaba as a mindfulness-based therapy in islamic psychotherapy," J. Relig. Health, vol. 58, pp. 1146-1160, 2019, doi: 10.1007/s10943-018-0695-y.

[21] B. Munif, S. Poeranto, and Y. W. Utami, "Effects of islamic spiritual mindfulness on stress among nursing students," Nurse Media J. Nurs., vol. 9, no. 1, pp. 69-77, 2019, doi: 10.14710/nmjn.v9i1.22253.

[22] E. Aslami, A. Alipour, F. S. Najib, and A. Aghayosefi, "A comparative study of mindfulness efficiency based on islamic-spiritual schemes and group cognitive behavioral therapy on reduction of anxiety and depression in pregnant women," Int $J$ Community Based Nurs Midwifery, vol. 5, no. 2, pp. 144-152, 2017.

[23] M. Dwidiyanti, B. Munif, A. Santoso, A. M. Rahmawati, and R. L. Prasetya, "DAHAGA: An Islamic spiritual mindfulness-based application to reduce depression among nursing students during the COVID-19 pandemic," Belitung Nurs. J., vol. 7, no. 3, pp. 219-226, 2021, doi: 10.33546/bnj.1494.

[24] M. S. Munsoor and H. S. Munsoor, "Well-being and the worshipper: A scientific perspective of selected contemplative practices in Islam," Humanomics, vol. 33, no. 2, pp. 163-188, 2017, doi: 10.1108/H-08-2016-0056.

[25] S. Ijaz, M. T. Khalily, and I. Ahmad, "Mindfulness in salah prayer and its association with mental health," J Reli. Heal., vol. 56, no. 6, pp. 2297-2307, 2017, doi: s10943-017-0413-1.

[26] C. S. Hendershot, K. Witkiewitz, W. H. George, and G. A. Marlatt, "Relapse prevention for addictive behaviors," Subst Abus. Treat Prev Policy, vol. 6, no. 17, 2011, doi: 10.1186/1747-597X-6-17.

[27] H. Snyder, "Literature review as a research methodology: An overview and guidelines," J. Bus. Res., vol. 104, pp. 333-339, 2019, doi: j.jbusres.2019.07.039.

[28] Muzakkir, Healthy and happy life in Sufism perspective (In Indonesia: Hidup sehat dan bahagia dalam perspektif tasawuf). Jakarta: Prenadamedia Group, 2018.

[29] H. Qudsy, A. Soleh, and N. Afsari, "Efforts to reduce academic cheating on students through peer education (In Indonesia: Upaya mengurangi kecurangan akademik pada mahasiswa melalui peer education)," Integritas, vol. 4, no. 1, pp. 77-100, 2018, doi: 10.32697/integritas.v4i1.168.

[30] Yaqeen Isntitute for Islamic Reserach, "How to be a mindful Muslim," Yaqeen Isntitute for Islamic Reserach, 2018.[Online]. Available: https://yaqeeninstitute.org/infographics/how-to-be-a-mindful-muslim-infographic\#.XVoq-uMzb-IU (accessed Sep. 13, 2021).

[31] S. I. I. Taimiyah, Tazkiyatun Nafs. Jakarta: Darus Sunah, 2018. Accessed: August 22, 2021.

[32] A. Kadafi, A. Alfaiz, M. Ramli, D. N. Asri, and J. Finayanti, "The impact of Islamic counseling intervention towards students' mindfulness and anxiety during the COVID-19 pandemic," Islam. Guid. Couns. J., vol. 4, no. 1, pp. 55-66, 2021, doi: 10.25217/igcj.v4i1.1018. Accessed: November 11, 2021.

[33] Y. A. Rahman, "Implementation of the concept of muahadah mujahadah, muraqabah, muhasabah and mu'aqabah in customer service (In Indonesia: Implementasi konsep muahadah mujahadah, muraqabah, muhasabah dan mu'aqabah dalam layanan customer)," J. Ekon. dan Bisnis Islam, vol. 8, no. 2, pp. 123-134, 2014.

[34] G. A. Marlatt and J. L. Kristeller, "Mindfulness and meditation," in Integrating spirituality into treatment: Resources for practitioners, W. R. Miller, Ed. American Psychological Association, 1999, pp. 67-84.

[35] K. S. Seybold and P. C. Hill, "The role of religion and spirituality in mental and physical health," Curr. Dir. Psychol. Sci., vol. 10, no. 1, pp. 21-24, Feb. 2001, doi: 10.1111/1467-8721.00106.

[36] D. R. Brown, J. S. Carney, M. S. Parrish, and J. L. Klem, “Assessing spirituality: the relationship between spirituality and mental health," J. Spiritual. Ment. Heal., vol. 15, no. 2, pp. 107-122, Apr. 2014, doi: 10.1080/19349637.2013.776442.

[37] Q. Uyun, I. N. Kurniawan, and N. Jaufalaily, "Repentance and seeking forgiveness: the effects of spiritual therapy based on Islamic tenets to improve mental health," Ment. Heal. Relig. Cult., vol. 22, no. 2, pp. 185-194, Feb. 2019, doi: $10.1080 / 13674676.2018 .1514593$.

[38] S. T. Gladding and J. E. Crockett, "Religious and spiritual issues in counseling and therapy: Overcoming clinical barriers," $J$. Spiritual. Ment. Heal., vol. 21, no. 2, pp. 152-161, Apr. 2019, doi: 10.1080/19349637.2018.1476947.

[39] R. Fazri, "Dhikr and wirid as a method of healing substance-related disorder (Case study: Sinar Jati Foundation in Bandar Lampung) (In Indonesia: Dzikir dan wirid sebagai metode penyembuhan penyakit substance-related disorder (Studi kasus: Yayasan Sinar Jati di Band), ” Thesis, Universitas Islam Negeri Raden Intan Lampung, 2018.

[40] Hadiarni, "Psychopathology due to social media addiction and Islamic counseling guidance as an alternative solution (In Indonesia: Psikopatologi akibat kecanduan media sosial dan bimbingan konseling islami sebagai alternatif solusi)," Proceeding Iain Batusangkar, 2016, vol. 1, no. 1, pp. 341-356.

[41] T. Machsun, "Drug Drug rehabilitation based on islamic religious education: case study at Pondok Tetirah Dzikir Berbah Rehabilitation Institution, Sleman Yogyakarta," in Proceedings of the 6th International Conference on Community Development (ICCD 2019), 2019, vol. 349, no. 6, pp. 623-626, doi: 10.2991/iccd-19.2019.164. Accessed: December 22, 2020.

[42] K. S. Najam, R. S. Khan, A. Waheed, and R. Hassan, "Impact of Islamic practiced on the mental health of muslims," Int. Dent. Med. J. Adv. Res., vol. 1, pp. 1-6, 2019, doi: 10.15713/ins.idmjar.99.

[43] K. Rajab, "Psychology for Islamic mental health," in Proceedings International Conference of Counseling Education and Psychology, 2018, pp. 1-14.

[44] W. M. Sabry and A. Vohra, "Role of Islam in the management of psychiatric disorders," Indian J Psychiatry, vol. 55, no. 2, pp. S205-S214, 2013, doi: 10.4103/0019-5545.105534.

[45] S. I. Rüschoff, "The importance of Islam religious philosophy for psychiatric practice," Psychiatr Prax, vol. 19, no. 2, pp. 39-42, 1992.

[46] M. A. Alfarisi, "Islamic psychotherapy for children and adolescents," SAWWA J. Stud. Gend., vol. 14, no. 1, pp. 21-30, 2019, doi: 10.21580/sa.v14i1.3788.

[47] Amiruddin, "Psycopathology and psychotherapy in Islam," MIQOT, vol. XXXIX, no. 2, pp. 341-355, 2015

[48] A. Haque, F. Khan, H. Keshavarzi, and A. E. Rothman, "Integrating Islamic traditions in modern psychology: Research trends in last ten years," J. Muslim Ment. Health, vol. 10, no. 1, pp. 75-100, 2016, doi: 10.3998/jmmh.10381607.0010.107.

[49] S. M. Melemis, "Relapse prevention and the five rules of recovery," Yale J Biol Med, vol. 88, no. 3, pp. 325-332, 2015.

[50] A. Haque, "Psychology from Islamic perspective: Contributions of early Muslim scholars and challenges to contemporary Muslim psychologists," J. Relig. Health, vol. 43, no. 4, pp. 357-377, 2004, doi: 10.1007/s10943-004-4302-z.

[51] F. Hamidi, Z. Bagherzadeh, and S. Gafarzadeh, "The role of islamic education in mental health," Procedia Soc. Behav. Sci., vol. 5, pp. 1991-1996, 210AD, doi: 10.1016/j.sbspro.2010.07.402. 


\section{BIOGRAPHIES OF AUTHORS}
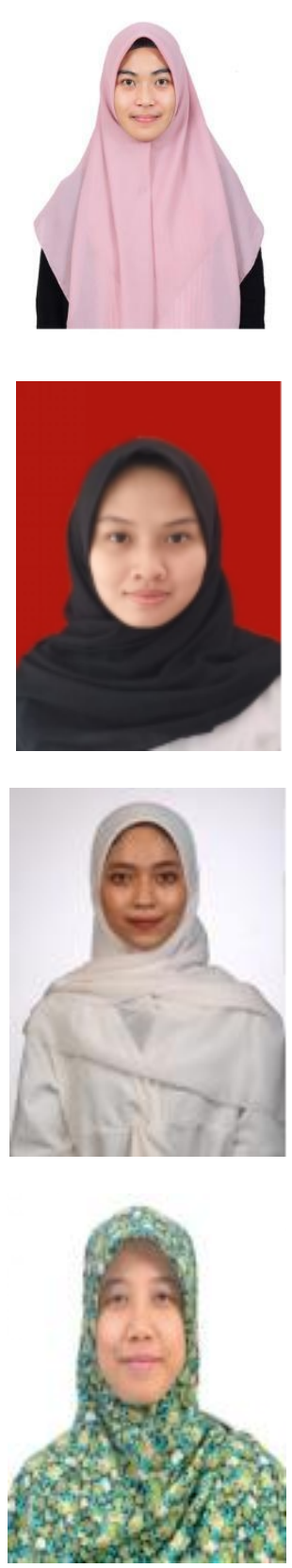

Winda Sri Harianti (D) $8 \mathrm{SC}$ P is bachelor student on faculty of psychology in Universitas Islam Indonesia. Currently she is studying in her final year of college. She had experience as a presenter on international and national conferences. She has a high interest in children and family studies, developmental \& clinical psychology, Islamic psychology, and psychotherapy. She also has received some awards for her achievements, such as $1^{\text {st }}$ Runner Up Indonesian Positive Psychology Ambassador awarded by Asosiasi Psikologi Positif Indonesia (AP2i) in $2019,1^{\text {st }}$ winner of best young psychology researcher in Indonesia and best paper on $5^{\text {th }}$ National Conference of Young Indonesian Psychology Researcher and awarded as social media ambassador of $7^{\text {th }}$ World Conference of Women's Studies and The $3^{\text {rd }}$ World Conference on Children and Youth by The International Institute of Knowledge Management (TIIKM) in 2021. She can be contacted at email: windasri17@gmail.com.

Rafifah Huwaida (D) Bd SC P is an undergraduate student of psychology in Universitas Islam Indonesia, Yogyakarta. Based on her education, she is interested in clinical psychology and Islamic psychology. She can be contacted at email: rafifahhuwaida@gmail.com.

Nindya Sekar Adriwiguna (D) SC SC is a final year student at Universitas Islam Indonesia (UII). She is interested in topics around psychology which are continuous with his education in psychology. She can be contacted at email: sekaradriwiguna@gmail.com.

Hazhira Qudsyi (D) 81 SC P is psychology lecture on faculty of psychology, Universitas Islam Indonesia. As a psychology lecturer, she is also a psychology researcher and counsellor in Universitas Islam Indonesia. In the field of research, she has published many scientific studies on proceeding, international and national journals. She also becomes one of the outstanding lecturers in Departement of Psychology, Universitas Islam Indonesia. She can be contacted at email: hazhira.qudsyi@uii.ac.id. 